\title{
Mimosine and Cyclophosphamide: a Potential New Combination Therapy Used to Prevent Tumor Development
}

\author{
Vânius Vinícius Dipe ${ }^{1}$, André Tadeu Gotardo ${ }^{1}$, Mitsue Haraguchi ${ }^{2}$ and Silvana Lima \\ Górniak $^{1 *}$ \\ ${ }^{l}$ Centro de Pesquisa de Toxicologia Veterinária; Faculdade de Medicina Veterinária e Zootecnia; Universidade de \\ São Paulo; 13635-900; São Paulo - SP - Brasil. ${ }^{2}$ Instituto Biologia de São Paulo; Av. Conselheiro Rodrigues Alves, \\ 1.252; 04014-002; São Paulo - SP - Brasil
}

\begin{abstract}
The effects of mimosine (MI), which is an amino acid that is derived from Leucaena leucocephala, were evaluated on the growth of ascitic Ehrlich tumors, and the effects of the combination treatment of MI and cyclophosphamide $(C Y)$ on tumor growth were also assessed. Mice were divided into groups that received the following treatments over the course of 20 days: phosphate buffer solution (CO), MI, Ehrlich cells (E), E plus CY (EC), E plus MI (EM) and E plus MI and CY (EMC). No signs of toxicity were detected in the mice from the MI group. The mice from the EMC group showed reductions in body weights when compared with those from the E group. The animals from the $E C, E M$ and EMC groups showed reductions in ascitic volume compared with those from the E group. The mice from the EMC group showed reductions in total cell numbers of ascitic fluid compared with those from the E, EC and EM groups. The combination of MI and CY was the most effective treatment for Ehrlich tumor ascites.
\end{abstract}

Key words: Leucaena leucocephala, Mimosine, Ehrlich tumor, Cyclophosphamide, Anticancer activity

\section{INTRODUCTION}

It is well known that many compounds with pharmacologic properties were first identified as poisonous substances; however, further investigations have revealed clinical therapeutic applications. In fact, botulinum toxins, which are exotoxins of Clostridium botulinum, are the most toxic naturally occurring substances known to man, but they also possess many clinical uses (Erbguth 2008). Many examples of poisonous plant-derived therapeutics have been reported in the literature, such as digoxin and digitoxin from Digitalis purpurea (Clark 1996), taxol from the Taxus species (Schiff and Horwitz 1980), pilocarpine from Pilocarpus jaborandi (Farnsworth et al. 1985) and many others.
Therefore, the greatest challenge for phytochemical and pharmacological studies involves the identification of the specific compounds that are responsible for the beneficial effects and their modes of action, thereby delineating their useful functions as therapeutic drugs.

Leucaena leucocephala is a species that originated in Central America and is now found in tropical regions around the world (Górniak 2008). This plant is highly nutritious, palatable and digestible for ruminants (Radostits et al. 2000). Additionally, it is a rich source of proteins, minerals and $\beta$-carotene (Akbar and Gupta 1985). However, many studies have shown that the use of leucaena forage has been limited due to its content of mimosine (MI) ( $\beta$-[N-(3-hydroxyl-4(1H)-

*Author for correspondence: gorniak@usp.br 
pyridone)], which is a non-protein amino acid that causes toxic effects in both ruminants and nonruminants (Radostits et al. 2000; Tokarnia et al. 2000), including alopecia, cataracts, gum atrophy, tongue and esophageal ulcerations, goiter, infertility and reduced weight gain (Radostits et al. 2000). It is known that cell mitotic activities in the epithelia of the esophagus, tongue, gums and intestines are high, and exposure to MI causes damage to these tissues (Hegarty et al. 1976). Many studies have been performed to better understand MI activity. Lalande and HanauskeAbel (1990) have shown that MI induces cell arrest (reversibly) late in the G1 phase of the cell cycle. Additionally, it is a tyrosine analog (Thompson et al. 1997) that contains a metalchelating domain. More specifically, it is able to chelate transition metals, such as $\mathrm{Fe}^{3+}$ (Linn et al. 1996), and the possible structure of the Fe (III)-MI chelation complex has been proposed by Tsai and Ling (1973). Furthermore, it has been demonstrated that MI inhibits various mammalian enzymes in vitro, such as tyrosinase, dopamine hydroxylase (Hashiguchi and Takahashi 1977), deoxyhypusyl hydroxylase (DOHH) (Abbruzzese et al. 1991), and H1 kinase (Feldman and Schonthal 1994). These results indicate that MI may inhibit the intense mitotic activity of cancer cells. In fact, in vitro studies have shown that MI represses uterine cancer cell growth (Zalatnai 2005) and blocks DNA replication in both breast cancer and Chinese hamster ovary cells (Mosca et al. 1992).

While many studies have been conducted to better understand the toxic effects of MI and its corresponding mechanism of action, information regarding its effects on tumor cells is lacking. Thus, the aim of this work was to evaluate the effects of MI on the growth of ascitic Ehrlich tumors in Swiss mice that received the MI treatment alone and in combination with a classic chemotherapeutic drug, cyclophosphamide (CY).

\section{MATERIALS AND METHODS}

\section{Mice}

Sixty male Swiss mice (sixty-day-old) that were bred at the Department of Pathology at the School of Veterinary Medicine and Animal Sciences, University of São Paulo, were used for the experiments. The mice were maintained under controlled temperature $\left(22-25^{\circ} \mathrm{C}\right)$, relative humidity (50-65\%) and lighting (12 h light/12 h dark cycles) conditions. Both drinking water and a standard diet Nuvilab- CR1@ from Nuvital Nutrientes LTDA (Curitiba, PR, Brazil) were provided ad libitum. All of the procedures were reviewed and approved by the Bioethics Committee of the FMVZ-USP (process number 2452/2011).

\section{Chemicals}

MI was obtained from Sigma Chemical Co. (St. Louis, MO) and initially dissolved in Tris buffer at $\mathrm{pH} 8.9$; the $\mathrm{pH}$ was subsequently adjusted to 7.2 with $1 \mathrm{~N} \mathrm{HCl}$. Before administration, the MI solution was freshly diluted with physiologic saline to the required concentration. Both dopalen (ketamine) and anasedan (xylazine) were obtained from Vetbrands (São Paulo, SP, Brazil). Genuxal (cyclophosphamide) was obtained from Astra Medica Oncologia (São Paulo, SP, Brazil).

\section{Tumor Model}

Ehrlich ascites carcinoma (EAC) cells that were syngeneic to Swiss mice were used for the tumor model in this study. The EAC cells were transplanted intraperitoneally (IP) into the Swiss mice, and only the fluid transplant generations that were passed over 12 times resulted in the formation of regular exudates. Before transplantation, the cells were washed three times in phosphate buffer solution, and cell viability was assayed via trypan blue exclusion. The tumor cells $\left(5 \times 10^{5}\right.$ cells) were injected (IP) on the first day of the experiment.

\section{Treatment Protocol and Evaluations}

MI was administered at $30.0 \mathrm{mg} / \mathrm{kg}$, and CY was administered at $12.5 \mathrm{mg} / \mathrm{kg}$. Sixty Swiss mice were randomly divided into 6 groups $(n=10)$ that received the following treatments by IP injection over the course of 20 days: phosphate-buffered saline (control group - CO), Ehrlich cells (E), Ehrlich cells plus MI (EM), Ehrlich cells plus CY (EC), Ehrlich cells plus MI and CY (EMC) and MI alone (MI). The animals from the MI group were used to insure that the MI dosage was not toxic. Ascitic volumes and tumor cellularities were not evaluated in the $\mathrm{CO}$ and $\mathrm{MI}$ groups because these animals did not receive tumor cells. One day after the last day of treatment, all of the animals were anesthetized with ketamine $(100 \mathrm{mg} / \mathrm{kg})$ and xylazine $(10 \mathrm{mg} / \mathrm{kg})$ and subjected to cervical dislocation, and the ascitic fluid was then collected 
and centrifuged at $4000 \mathrm{rpm}$ for $10 \mathrm{~min}$. The supernatant was discarded, and the cells were resuspended in phosphate buffer solution (PBS). This solution was diluted in trypan blue, and the total live and dead cells were quantified using a Neubauer chamber. Body weight gain was measured on the first and last days of treatment. The incidence of alopecia was observed daily by visual inspection.

\section{Statistical Analysis}

The data were analyzed with GraphPad Prism $5.00^{\circledR}$ software (GraphPad Software, Inc., San Diego, CA) using the one-way analysis of variance (ANOVA) followed by Tukey's test for multiple comparisons. Data were expressed as the mean \pm $\mathrm{SD}$, and the differences were considered to be statistically significant at $\mathrm{p}<0.05$.

\section{RESULTS}

The animals from the EMC group showed significant reductions $(\mathrm{p}<0.05)$ in body weight gain (Fig. 1A) compared with those from the $\mathrm{E}$ group. The same differences were detected when comparing the animals from the $\mathrm{CO}$ and $\mathrm{MI}$ groups. Additionally, the ascitic volumes that were observed in the mice from the EMC, EC and EM groups were lower than those from the $\mathrm{E}$ group (Fig. 1B); however, the EMC mice displayed smaller volumes compared with those from the EM and EC groups. The EMC mice also showed reductions in tumor cell numbers (Fig. 2A) compared with those from all of the other groups. Additionally, statistical analyses revealed that the live and dead tumor cells (Figs. 2B and 2C) were reduced exclusively in the mice from the EMC group compared with those from the E group.
A

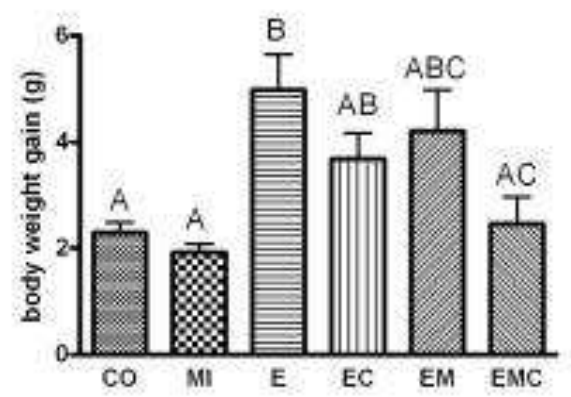

B

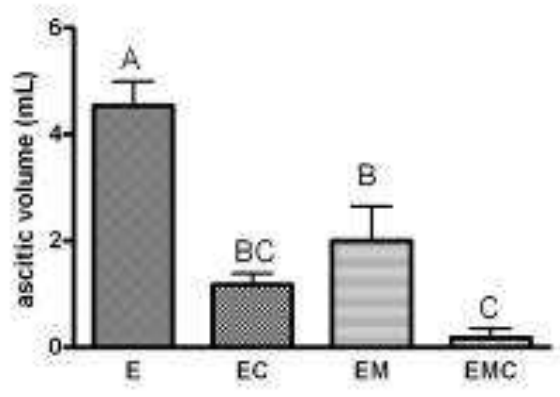

Figure 1 - The body weight (A) and ascitic volume (B) measurements that were obtained from the mice that received 20 days of treatment with $\mathrm{CY}$ and/or MI and no treatment. Phosphate-buffered saline (control group - CO), MI alone (MI), Ehrlich cells (E), Ehrlich cells plus CY (EC), Ehrlich cells plus MI (EM) and Ehrlich cells plus MI and CY (EMC). The letters indicate the statistical significances at $\mathrm{p}<0.05$ as determined via Tukey's test. 


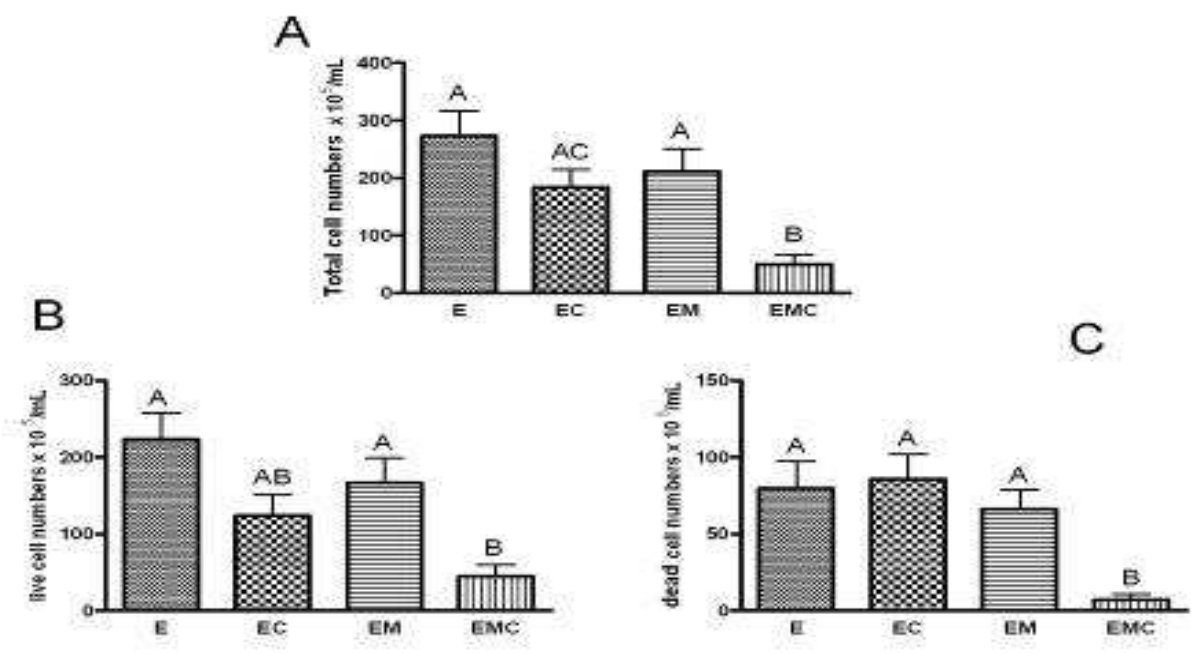

Figure 2 - The total cell (A), live cell (B), and dead cell numbers (C) of the ascitic Ehrlich tumors that were isolated from the mice that were either treated with $\mathrm{CY}$ and/or MI or untreated for 20 days. Ehrlich cells (E), Ehrlich cells plus CY (EC), Ehrlich cells plus MI (EM), and Ehrlich cells plus MI and CY (EMC). The letters indicate the statistical significances at $\mathrm{p}<0.05$ as calculated via Tukey's test.

\section{DISCUSSION}

The Ehrlich tumor, which is derived from a mouse adenocarcinoma, has been used as a transplantable tumor model to investigate the antineoplastic effects of many substances and compounds. Following the intraperitoneal inoculation of Ehrlich tumor cells, ascitic volumes increase progressively (Vincent and Nicholls 1967). This ascitis likely occurs due to tumor-induced inflammation resulting from the increased peritoneal vascular permeability (Fastaia and Dumont 1976). The impaired peritoneal lymphatic drainage by tumor cells (Fastaia and Dumont 1976), the mechanic pressure that is exerted by the progressive increase in ascitic fluid, intraperitoneal hemorrhage and endotoxemia represent additional consequences of Ehrlich ascitic tumor development, which result in the death of the affected animals (Hartveit 1965; Mayer 1966).

The aggressiveness of the Ehrlich tumor and its rapid growth make it a good model to investigate the possible synergistic effects of anticancer therapies using different mechanisms of action, as verified in a recent study that was conducted by Santos et al. (2011), in which treatment with a plant compound was analyzed in combination with the chemotherapeutic drug, cisplatin. In our study, this model also permitted the assessment of whether MI and CY cause any interactions and/or reduce tumor development.

Many chemotherapeutic agents and drug combinations are very toxic to patients; for example, doxorubicin-associated cardiotoxicity (Mackay et al. 1994), the hepatotoxicity of cisplatin (Cavalli et al. 1978; Cersosimo 1993; Pollera et al. 1987) and the neurotoxicity of paclitaxel (Postma et al. 1995). In this study, we verified that MI-treated mice did not display any reductions in body weight or show any other clinical manifestations of MI-induced toxicity, such as hair loss (Crounse et al. 1962). Therefore, the dose that was applied in this study does not appear to be toxic; however, additional studies using accurate protocols of toxicological evaluation are necessary to confirm this hypothesis. While no differences in the tumor cells were detected between the mice from the Ehrlich cell (E) group and those from the isolated treatment (CY and MI) groups, consistent differences were observed when the animals were treated with the $\mathrm{CY}$ and $\mathrm{MI}$ combination treatment, which suggests that this combination is effective in restricting ascitic tumor development.

$\mathrm{CY}$ is one of the most important alkylating drugs that is currently employed to treat cancer, and its mechanism of action involves the prevention of cell division primarily by the cross-linking of 
DNA and RNA strands, which interrupts mitosis (Fleming 1997). In contrast, it has been proposed that MI acts as an iron chelator (Kulp and Vulliet 1996), and it is known that iron deficiency alters folate metabolism in mammals and can interfere with tumor cell growth (Gilbert et al. 1998).

Goldin and Mantel (1957) have proposed that the synergic mechanism of xenobiotics results in tumor damage because each agent acts on different cellular metabolic pathways. Thus, it is possible that synergism occurred when the amino acid was combined with the chemotherapeutic agent; moreover, MI and CY likely act in a synergistic fashion due to their varying antimetabolic properties.

Additionally, MI inhibited Ehrlich tumor growth via its activity in the immune system. In fact, a study that was conducted by Frydas et al. (2003) has verified that in mice with experimentally induced subcutaneous granulomas that were treated with IP injections of MI, significantly decreased granuloma sizes and weights and the strong inhibition of TNF- $\alpha$ were displayed in both their sera and granulomas. Thus, future studies evaluating the immune systems of animals that have been treated with MI would assist in further verification.

In conclusion, this work proposes a new combination treatment that inhibits tumor development. Our results reveal that MI enhances Ehrlich carcinoma cell sensitivity to $\mathrm{CY}$ as demonstrated by the improvement in the effectiveness of the antitumor treatment following combination therapy. However, further studies must be performed to verify the impacts of the toxic effects of MI during prolonged exposure.

\section{ACKNOWLEDGMENTS}

This research was supported by grants from the CNPq (Conselho Nacional de Desenvolvimento Científico e Tecnológico) and CAPES (Coordenação de Aperfeiçoamento de Pessoal de Nível Superior).

\section{REFERENCES}

Abbruzzese A, Hanauske AHM, Park MH, Henke S, Folk JE. The active site of deoxyhypusyl hydroxylase: use of catechol peptides and their component chelator and peptide moieties as molecular probes. Biochim Biophys Acta. 1991; 1077:159-66.

Akbar MA, Gupta PC. Subabul (Leucaena leucocephala) as a source of protein supplement for buffalo calves. Indian J Anim Sci. 1985; 55:54-8.

Cavalli F, Tschopp L, Sonntag RW, Zimmermann A. Cisplatin-induced hepatic toxicity. Cancer Treat Rep. 1978; 62:2125-6.

Cersosimo RJ. Hepatotoxicity associated with cisplatin chemotherapy. Ann Pharmacother. 1993; 27: 438-41.

Clark AM. Natural products as a resource for new drugs. Pharmaceutical Res. 1996; 13:1133-41.

Crounse RG, Maxwell JD, Blank H. Inhibition of growth of hair by mimosine. Nature. 1962; 194:6945.

Erbguth FJ. From poison to remedy: the chequered history of botulinum toxin. J Neural Transm. 2008; 115:559-65.

Farnsworth NR, Akerele O, Bingel AS, Soejarto DD, Guo Z. Medicinal Plants in Therapy. Bull WHO. 1985; 63: 965-81.

Fastaia J, Dumont A. Pathogenesis of ascites in mice with peritoneal carcinomatosis. J Natl Cancer Inst. 1976; 56: 547-9.

Feldman ST, Schonthal A. Negative regulation of histone H1 kinase expression by mimosine, a plant amino acid. Cancer Res. 1994; 54:494-8.

Fleming RA. An overview of cyclophosphamide and ifosfamide pharmacology. Pharmacotherapy. 1997; 17:146- 54.

Frydas S, Papazahariadou M, Papaioannou N, Hatzistilianou M, Trakatellis M, Merlitti D, et al. Effect of the compound L-mimosine in an in vivo model of chronic granuloma formation induced by potassium permanganate (KMNO4). Int $J$ Immunopathol Pharmacol. 2003; 16:99-104.

Gilbert DM, Neilson A, Miyazawa H, Depamphilis ML, Gupta HK, Altreja PP. Influence of ferric chloride treated Leucaena leucocephala on metabolism of mimosine and 3-hydroxy-4 $(1 \mathrm{H})$-pyridone in growing rabbits. Anim Feed Sci Tech. 1998; 74:45-55.

Goldin A, Mantel N. The employment of combinations of drugs in the chemotherapy of neoplasia: A review. Cancer Res. 1957; 17:635-54.

Górniak SL. Plantas tóxicas de interesse agropecuário. In: GÓRNIAK SL, SPINOSA HS, PALERMONETO J, editors. Toxicologia aplicada à Medicina Veterinária. Barueri: Manole; 2008. p. 415-58.

Hartveit F. The imediate cause of death in mice with Ehrlich ascites carcinoma. Acta Path Microb Scand. 1965; 65:359-65.

Hashiguchi H, Takahashi $H$. Inhibition of two coppercontaining enzymes, tyrosinase and dopamine betahydroxylase, by L-mimosine. Mol Pharmacol. 1977; 13:362-7.

Hegarty MP, Court RD, Christie GS, Lee CP. Mimosine in Leucaena Zeucocephala is metabolized to a goitrogen in ruminants. Aust Vet J. 1976; 52:490. 
Kulp KS, Vulliet PR. Mimosine blocks cell cycle progression by chelating iron in asynchronous human breast cancer cells. Toxicol Appl Pharmacol. 1996; 139:356-64.

Lalande M, Hanauske-Abel HM. A new compound which reversibly arrests $\mathrm{T}$ lymphocyte cell cycle near the G1/S boundary. Exp Cell Res. 1990; 188:117-21.

Linn HB, Falchetto R, Mosca PJ, Shabanowitz J, Hunt DF, Hamlin JL. Mimosine targets serine hydroxymethyltransferase. Biol Chem. 1996; 271:2548-56.

Mackay B, Ewer MS, Carrasco CH, Benjamin RS. Assessment of anthracycline cardiomyopathy by endomyocardial biopsy. Ultrastruct Pathol. 1994; 18:203-11.

Mayer K.D. The pathogenicity of the Ehrlich ascites tumor. Brit J Exp Path. 1966; 47:537-44.

Mosca PJ, Dijkwel PA, Hamlin JL. The plant amino acid mimosine may inhibit initiation at origins of replication in Chinese hamster cells. Mol Cell Biol. 1992; 12:4375-83.

Pollera CF, Meglio F, Nardi M, Vitelli G, Marolla P. Cisplatin-induced hepatic toxicity. J Clin Oncol. 1987; 5: 318-9.

Postma TJ, Vermorken JB, Liefting AJM, Pinedo HM, Heimans JJ. Paclitaxel-induced neuropathy. Ann Oncol. 1995; 6:489-94.

Radostits OM, Blood DC, Gay CC. Veterinary Medicine. 8th ed. London: Bailliere Tindal; 2000.
Santos FM, Latorre AO, Hueza IM, Sanches DS, Lippi LL, Gardner DR, et al. Increased antitumor efficacy by the combined administration of swainsonine and cisplatin in vivo. Phytomedicine. 2011; 18:1096-101.

Schiff PB, Horwitz SB. Taxol stabilizes micrombules in mouse fibroblast cells. Proc Natl Acad Sci U.S.A.1980; 77:1561-5.

Thompson JF, Morris CJ, Smith IK. New naturally occurring amino acids. Annu Rev Biochem.1969; 38:137-58.

Tokarnia CH, Döbereiner J, Peixoto PV. Plantas Tóxicas do Brasil. Rio de Janeiro: Helianthus; 2000.

Tsai WC, Ling KH. Study on the stability constant of some metal ion chelatea of mimosine and 3,4tihydroxypyridine. J Chin Biochem Soc. 1973; 2:7086.

Vincent PC, Nicholls A. Comparision of the growth of the Ehrlich ascites tumor in male and female mice. Cancer Res. 1967; 27:1058-65.

Zalatnai A. P-glycoporotein expression is induced in human pancreatic xenografts during treatment with a cell cyclo regulator, mimosine. Pathol Oncol Res. 2005; 11:164-9.

Received: June 27, 2011; Revised: October 27, 2011; Accepted: June 28, 2012. 